\title{
Inhibitory roles of the mammalian GnIH ortholog RFRP3 in testicular activities in adult mice
}

\author{
Shabana Anjum, Amitabh Krishna and Kazuyoshi Tsutsui ${ }^{1}$ \\ Department of Zoology, Banaras Hindu University, Varanasi 221 005, Uttar Pradesh, India \\ ${ }^{1}$ Department of Biology, Waseda University, Tokyo 162-8480, Japan
}

Correspondence should be addressed to A Krishna

Email

akrishna_ak@yahoo.co.in

\begin{abstract}
The aim of this study was to evaluate the effects of in vivo and in vitro treatments with RFamide-related peptide 3 (RFRP3), a mammalian gonadotropin-inhibitory hormone ortholog, on testicular activities, i.e. spermatogenesis and steroidogenesis, in mice. Mice were treated in vivo with different doses of RFRP3 (control: $0.02 \mu \mathrm{g}, 0.2 \mu \mathrm{g}$, and $2.0 \mu \mathrm{g} / \mathrm{day}$ ) for 8 days. For in vitro study, the testes of mice were evaluated with different doses of RFRP3 (control: 1 and $10 \mathrm{ng} / \mathrm{ml}$ ) with or without LH (control: 10 and $100 \mathrm{ng} / \mathrm{ml}$ ) for $24 \mathrm{~h}$ at $37{ }^{\circ} \mathrm{C}$. RFRP3 treatment produced significant changes in the body mass, circulating steroid level, and testicular activity in mice. RFRP3 treatment also caused dose-dependent histological changes in spermatogenesis, such as decline in germ cell proliferation and survival markers and increase in apoptotic markers in testis. Both in vivo and in vitro studies showed the inhibitory effect of RFRP3 on testosterone synthesis in the testis. RFRP3 inhibited the expression of the receptor for LH (LHCGR), STAR protein, cytochrome P450 side-chain cleavage (CYP11A1) and 3 $\beta$-hydroxysteroid dehydrogenase in the testis, and testosterone secretion dose dependently. This study also suggested that the inhibitory effect of RFRP3 in the testis may be mediated through local production of GnRH. Thus, RFRP3 inhibits testicular steroidogenesis and spermatogenesis either indirectly through $\mathrm{GnRH}$ or by directly influencing germ cell proliferation, survival, and apoptosis.
\end{abstract}

\author{
Key Words \\ - RFamide-related peptide 3 \\ - gonadotropin-inhibitory \\ hormone \\ - steroidogenesis \\ - spermatogenesis \\ - testis \\ - mice
}

Journal of Endocrinology (2014) 223, 79-91

\section{Introduction}

Gonadotropin-releasing hormone (GnRH) is a hypothalamic decapeptide hormone known to regulate reproductive functions in mammals by modulating the biosynthesis and release of gonadotropins, namely luteinizing hormone (LH) and follicle-stimulating hormone, from anterior pituitary gland. In addition to its role at the level of pituitary, GnRH and its receptor are located in the testis of mammals and other vertebrates and regulate steroidogenesis, spermatogenesis, and apoptosis in the testis (Sinha Hikim \& Swerdloff 1999). A hypothalamic dodecapeptide (12 amino acids) having LPXRFamide motif at its C-terminal end was isolated from quail brain in the year 2000, which inhibits gonadotropin release and thus was named as gonadotropin-inhibitory hormone (GnIH) (Tsutsui et al. 2000). GnIH, acting via GPR147, can suppress the testosterone secretion and spermatogenesis by acting at all levels of the hypothalamic-pituitarygonadal axis of birds and mammals (for reviews, see Tsutsui (2009), Tsutsui et al. $(2010 a, b)$, and Ubuka et al. (2014)). GnIH orthologous peptides that possess LPXRFamide $(\mathrm{X}=\mathrm{L}$ or $\mathrm{Q})$ motif at their $\mathrm{C}$-termini have been documented in mammals including primates and humans 
and other vertebrates (for reviews, see Tsutsui (2009) and Tsutsui et al. $(2010 a, b))$. In mammals, these GnIH orthologs are also known as RFamide-related peptides (RFRPs; for reviews, see Tsutsui (2009) and Tsutsui et al. $(2010 a, b))$. Tsutsui et al. proposed that RFRPs are the mammalian GnIH structural orthologs (for reviews, see Tsutsui (2009) and Tsutsui et al. (2010a,b)). RFRP3 has the potential to modulate $\mathrm{GnRH}$ secretion in the brain of mammals (Ubuka et al. 2009b).

cDNAs encoding GnIH precursor polypeptides were identified by a combination of $3^{\prime}$ and $5^{\prime}$ rapid amplification of cDNA ends ( $3^{\prime} / 5^{\prime}$ RACE) in quail (Satake et al. 2001) and other avian species (for reviews, see Tsutsui (2009) and Tsutsui et al. $(2010 a, b))$. cDNAs that encode LPXRFamide $(\mathrm{X}=\mathrm{L}$ or $\mathrm{Q}$ ) peptides have been investigated in mammals by a gene database search (Hinuma et al. 2000). The precursor cDNAs identified from mammals encoded two LPXRFamide ( $\mathrm{X}=\mathrm{L}$ or $\mathrm{Q}$ ) peptides (RFRP1 and RFRP3). Human, macaque, and bovine precursor cDNAs encoded LPXRFamide-like peptide, which was named RFRP2. However, rodent precursor cDNA did not encode RFRP2 (for reviews, see Tsutsui (2009) and Tsutsui et al. $(2010 a, b)$ ). The mammalian GnIH orthologs, RFRP1 and/or RFRP3, were also identified as mature peptides in bovine (Fukusumi et al. 2001, Yoshida et al. 2003), rat (Ukena et al. 2002), Siberian hamster (Ubuka et al. 2012), monkey (Ubuka et al. 2009a), and human (Ubuka et al. 2009b).

Immunohistochemical studies indicated that GnIHimmunoreactive (-ir) cell bodies exist in the paraventricular nucleus in birds (Tsutsui et al. 2000, Ukena et al. 2003) and dorsomedial hypothalamic area in mammals (Kriegsfeld et al. 2006, Ubuka et al. 2012). GnIH-ir axon terminals are in probable contact with GnRH neurons in birds (Bentley et al. 2006, Ubuka et al. 2008), rodents (Kriegsfeld et al. 2006, Ubuka et al. 2012), monkeys (Ubuka et al. 2009a), and humans (Ubuka et al. 2009b). Based on previous studies, it is considered that GnIH and mammalian GnIH orthologs, RFRP1 and RFRP3, inhibit the secretion of gonadotropins by decreasing the activity of GnRH neurons in addition to directly regulating pituitary gonadotropin secretion in birds and mammals (for reviews, see Tsutsui (2009) and Tsutsui et al. 2010a,b, 2013)). GPR147, a G protein-coupled receptor, is a GnIH receptor (GnIHR; Yin et al. 2005). GnIHR can bind with a high affinity to GnIH (Yin et al. 2005) and RFRPs (Hinuma et al. 2000), which have LPXRFamide $(\mathrm{X}=\mathrm{L}$ or $\mathrm{Q})$ motif at their C-termini. Accordingly, GnIHR (GPR147) plays important roles in regulating reproductive activities in birds and mammals (for reviews, see Tsutsui (2009), Tsutsui et al. (2010a,b), and Ubuka et al. (2014)).
Besides neurons in hypothalamus, the expressions of GNRH1 and GnIH in multiple extrahypothalamic and pituitary sites have been demonstrated (Hsueh \& Schaeffer 1985, McGuire \& Bentley 2010). These findings suggest that not only GnRH but also GnIH possess multiple functions other than neuroendocrine regulation. Recently, GnIH or RFRP3 and its receptor were identified in gonads and the accessory reproductive organ of birds and mammals (Bentley et al. 2006, McGuire \& Bentley 2010, Singh et al. 2011a). In the testis, the expressions of RFRP3 and its receptor have been demonstrated in rhesus macaque (Macaca mulatta) (Ubuka et al. 2009a) and Syrian hamster (Zhao et al. 2010). Thus, there is potential for a highly localized autocrine or paracrine effect of GnIH/RFRPs on a variety of gonadal function in birds and mammals.

Until date, there is only a limited study on the functional significance of RFRP3 on mammalian testis. We therefore sought to comprehensively examine the functional role of RFRP3 in the regulation of testicular activities with particular reference to spermatogenesis and steroidogenesis in mice. To study the in vivo effect of RFRP3 on spermatogenic activity, changes in histological features together with changes in the rate of cell survival (expression of $\mathrm{Bcl} 2$ ), proliferation (localization of proliferating cell nuclear antigen (PCNA)), and apoptosis (expression of caspase 3 and poly(adenosine diphosphate-ribose) polymerase (PARP1 proteins) were evaluated in the testis of mice. As an in vivo study alone allows for the determination of direct together with indirect effects, an in vitro study was also planned in this study in order to demonstrate a direct action of RFRP3 on testis. We have recently reported the RFRP3 function in relation with the GnRH system in the gonad (Anjum et al. 2012), suggesting that RFRP3 is a part of a complex system of gonadal regulation. To study the effect of RFRP3 on steroidogenesis, the rate of testicular expressions of GNRH receptor (GNRHR), LH-receptor (LHCGR), STAR protein, cytochrome P450 side-chain cleavage (CYP11A1), and $3 \beta$-hydroxysteroid dehydrogenase (HSD3B) were evaluated.

\section{Materials and methods}

\section{Animals}

All experiments were conducted in accordance with the principles and procedures of the 2002 Animal act, India, and approved by the Animal Ethical Committee, Banaras Hindu University. Male laboratory mice (Mus musculus) of

Published by Bioscientifica Ltd 
Parkes strain were obtained from the inbred colony maintained in our animal house. Adult mice (13 weeks old) of almost equal body mass were used in this study. Mice were housed under constant conditions of temperature and humidity in a photoperiodically controlled room (12 h light:12 $\mathrm{h}$ darkness) and were provided with commercial food (Pashu Aahar Kendra, Varanasi, India) and tap water ad libitum.

\section{Chemicals}

Mouse RFRP3 (VNMEAGTRSHFPSLPQRF-NH ${ }_{2}$ ), a mouse GnIH ortholog, was kindly provided by Tsutsui, Department of Biology, Waseda University, Tokyo, Japan (Son et al. 2012). All the general chemicals used in this study were purchased from Merck. For immunohistochemistry (IHC), the $\mathrm{ABC}$ staining kit was purchased from Universal Elite, Vector Laboratories (Burlingame, CA, USA).

\section{In vivo study}

Mice were daily injected, intraperitoneally, with RFRP3 for 8 days. Mice in the control group $(n=10)$ received vehicle only. Based on previous studies, three different doses of RFRP3 $(0.02 \mu \mathrm{g}, 0.2 \mu \mathrm{g}$, and $2.0 \mu \mathrm{g}$ /day per body weight; $n=10$ per group) dissolved in normal saline solution were selected for the treatment (Ubuka et al. 2006, Singh et al. $2011 b$ ). The animals were killed by decapitation under a mild dose of anesthetic ether within 30 min after the last injection and blood was collected. Body mass of each mouse was recorded before killing. Testes were excised out, cleaned, and weighed. The testis from one side from each animal was stored and kept at $-40{ }^{\circ} \mathrm{C}$ for immunoblot analysis and $3 \beta$-HSD activity and testes from the other side were fixed in Bouin's fixative for histological analysis and Immunohistochemical study.

The liver was excised out from each animal, cleaned, and fixed in Bouin's fixative for histological analysis.

Gonadosomatic index (GSI) was determined using the formula:

GSI/100 g of BW $=\frac{\text { Testis weight }}{\text { Body weight }} \times 100$.

\section{Histological analysis}

Testes were embedded in paraffin wax and serially sectioned at $5 \mu \mathrm{m}$; two sets of slides were prepared. One set was used for hematoxylin and eosin staining and the other set was used for IHC. Quantitative analyses of spermatogenesis were carried out by counting the number of each type of germ cell at various stages, particularly at stage VII of the seminiferous cycle (Russell et al. 1990). This stage was chosen because it is the most frequent stage of spermatogenesis and contains spermatogonia (SG) B, preleptotene ( $\mathrm{Pl}$ ) spermatocytes, pachytene spermatocytes, and spermatids. For this purpose, five slides were selected from one animal and two sections from each slide were taken for counting. Type A SG, Pl spermatocyte, pachytene (P) spermatocyte, and step 7 spermatids (7Sd) were counted according to the method of Leblond \& Clermont (1952). The nuclei of different germ cells were counted in 100 round seminiferous tubules (STs) per treatment group. All the counts (crude counts) of germ cell were corrected for the section thickness and differences in the nuclear or nucleolar diameter using Abercrombie's formula (Abercrombie 1946).

$P=A \frac{M}{L+M}$,

where $P$ is the average number of nuclear points per section, $A$ the crude count of nuclei in the section, and $M$ the thickness $(\mu \mathrm{m})$ of nuclei. The results are expressed as corrected count of germ cells.

\section{In vitro study}

The different doses of RFRP3 ( 1 and $10 \mathrm{ng} / \mathrm{ml}$ ) with or without LH (10 and $100 \mathrm{ng} / \mathrm{ml})$ were selected based on a previous study (Ubuka et al. 2006, Anjum \& Krishna 2012). Adult male mice $(n=4)$ were killed by decapitation under a mild dose of anesthetic ether immediately after they were brought to the laboratory. Their testes were quickly dissected out and cleaned of any adhered fat tissue in DMEM (Himedia, Mumbai, India) containing $250 \mathrm{U} / \mathrm{ml}$ penicillin and $250 \mu \mathrm{g} / \mathrm{ml}$ streptomycin sulfate. The testes were cut into equal pieces $(\sim 10 \mathrm{mg}$ in weight) and cultured by the method as described previously (Anjum et al. 2012). Culture medium was a mixture of DMEM (with sodium pyruvate and L-glutamine) and Ham's F-12 $(1: 1 ; \mathrm{v}: \mathrm{v})$ (Himedia) containing $100 \mathrm{U} / \mathrm{ml}$ penicillin, $100 \mu \mathrm{g} / \mathrm{ml}$ streptomycin, and $0.1 \%$ BSA (Sigma). After initial incubation for $2 \mathrm{~h}$ at $37^{\circ} \mathrm{C}$, culture medium was discarded and testes (one per tube) were finally cultured in $1 \mathrm{ml}$ medium in a humidified atmosphere with $95 \%$ air and $5 \% \mathrm{CO}_{2}$ to maintain $\mathrm{pH} 7.4$ for $24 \mathrm{~h}$ at $37^{\circ} \mathrm{C}$. Each treatment group was run in triplicate. Testes cultured under these conditions appear healthy and do not show any sign of necrosis. Testis slices were collected at the end

Published by Bioscientifica Ltd. 
of culture, washed several times with PBS, and stored at $-40{ }^{\circ} \mathrm{C}$ for immunoblot study, and media were collected and stored at $-40{ }^{\circ} \mathrm{C}$ until testosterone assay.

\section{Serum aspartate aminotransferase and alanine aminotransferase (toxicological parameters)}

To observe the effect of RFRP3 on liver function, serum alanine aminotransferase (ALT) and aspartate aminotransferase (AST) were determined using kits (Span diagnostic, Surat, India) as per the manufacturer's instructions.

\section{Testosterone assay}

ELISA Kit for testosterone assay was purchased from Dia Metra, Giustozzi (Foligno (PG), Italy; lot no.: DKO002) and was validated by spiking control (Banerjee et al. 2012). Standard, control, or sample each of $25 \mu \mathrm{l}$ was added to each well of the ELISA plate. Subsequently, $100 \mu$ l of the diluted conjugate solution were added to each of these wells. The ELISA plate was then incubated with mild shaking at $37^{\circ} \mathrm{C}$ for $1 \mathrm{~h}$. The wells were then aspirated and washed several times with distilled water. Then, $100 \mu \mathrm{l}$ of the tetramethyl benzidine chromogen substrate were added to each well and the plate was incubated at room temperature for $15 \mathrm{~min}$ in the dark. Finally, $100 \mu \mathrm{l}$ of stop solution were added and absorbance was measured at a wavelength of $450 \mathrm{~nm}$ using a microplate reader. The standard curve ranged from 0.2 to $16 \mathrm{ng} / \mathrm{ml}$. Unknowns were run within the narrow range representing the most linear portion of the standard curve. The coefficient of intra-assay variation was $5.4 \%$ and that of inter-assay variation was $15 \%$. The lowest detectable concentration of testosterone that can be distinguished from the zero standards is $0.07 \mathrm{ng} / \mathrm{ml}$ at the $95 \%$ confidence limit.

\section{Immunohistochemistry}

IHC was performed for PCNA in serial sections. Briefly, after deparaffinization and hydration, endogenous peroxidase was quenched with $0.3 \% \mathrm{H}_{2} \mathrm{O}_{2}$ and equilibrated in $0.05 \mathrm{~mol} / 1$ Tris-HCl, $0.15 \mathrm{~mol} / \mathrm{l} \mathrm{NaCl}$ (TBS, pH 7.3). Background blocking was performed with the normal horse serum. The tissue sections were incubated with the primary antibody PCNA (see Table 1) in PBS overnight at $4{ }^{\circ} \mathrm{C}$. The detection system used was the ABC staining kit. The peroxidase activity was revealed in $0.03 \% 3,3^{\prime}$ diaminobenzidine tetra-dihydrochloride (DAB; Sigma) in $0.01 \mathrm{M}$ Tris- $\mathrm{HCl}(\mathrm{pH} 7.6)$ and $0.1 \% \mathrm{H}_{2} \mathrm{O}_{2}$. Slides were then dehydrated and mounted and viewed under a light microscope (Nikon Eclipse E200, Tokyo, Japan) and photographed. The control was performed by replacing the primary or secondary antibody with PBS.

The number of PCNA immunopositive germ cells per ST within a section of testis was quantified using computer-assisted image analysis (Image J $1.48 \times$, NIH, USA). Randomly selected 20 STs from the sections of testis were examined at $40 \times$ objective with a Nikon Eclipse E200 light microscope. The testis from five mice from each treated and control groups were analyzed. The mean

Table 1 Details of antibodies used for immunohistochemistry and slot/western blot

\begin{tabular}{|c|c|c|c|c|c|}
\hline Antibody & $\begin{array}{l}\text { Target } \\
\text { species }\end{array}$ & $\begin{array}{l}\text { Species raised in; } \\
\text { monoclonal/polyclonal }\end{array}$ & Source & $\begin{array}{l}\text { Concentration } \\
\text { (use for } \mathrm{IHC} \text { ) }\end{array}$ & $\begin{array}{l}\text { Concentration (used } \\
\text { for western/slot blot) }\end{array}$ \\
\hline GnRH & Human & Rabbit; polyclonal & $\begin{array}{l}\text { Peninsula Lab, Inc. } \\
\text { (San Carlos, CA, USA; IHC-72011) }\end{array}$ & & $1: 5000$ \\
\hline GnRHR & Human & Rabbit; polyclonal & $\begin{array}{l}\text { Santa Cruz Biotechnology, Inc. } \\
\quad(\mathrm{N}-20, \mathrm{SC} 8682)\end{array}$ & & $1: 1000$ \\
\hline LHR & Human & Rabbit; polyclonal & $\begin{array}{l}\text { Santa Cruz Biotechnology, Inc. } \\
\quad(\mathrm{N}-20, \text { SC 25828) }\end{array}$ & & $1: 500$ \\
\hline StAR & Human & Rabbit; polyclonal & $\begin{array}{l}\text { Santa Cruz Biotechnology, Inc. } \\
\quad(\mathrm{N}-20, \text { SC 25806) }\end{array}$ & & $1: 500$ \\
\hline $\begin{array}{l}\text { Cytochrome } \\
\text { P450 SCC }\end{array}$ & Rat & Rabbit; polyclonal & $\begin{array}{l}\text { Millipore } \\
\text { (Tamecula, CA, USA; AB1244) }\end{array}$ & & $1: 500$ \\
\hline Caspase 3 & Human & Rabbit; polyclonal & $\begin{array}{l}\text { BioVision, Inc. } \\
\text { (Milpitas, CA, USA; } \\
\text { cat no. 3015-100) }\end{array}$ & & $1: 1000$ \\
\hline PARP & Human & Rabbit; polyclonal & $\begin{array}{l}\text { Santa Cruz Biotechnology, Inc. } \\
\quad(\mathrm{N}-20, \mathrm{SC} 7150)\end{array}$ & & $1: 500$ \\
\hline $\mathrm{Bcl} 2$ & Human & Rabbit; polyclonal & $\begin{array}{l}\text { Santa Cruz Biotechnology, Inc. } \\
\quad(\mathrm{N}-20, \text { SC 492) }\end{array}$ & & $1: 200$ \\
\hline PCNA & Human & Rabbit; polyclonal & $\begin{array}{l}\text { Thermo Fisher Scientific } \\
\text { (Rockford, IL, USA; PA1-38424) }\end{array}$ & $1: 200$ & $1: 300$ \\
\hline Actin & $\beta$-actin & Mouse; monoclonal & Sigma (A2228, 128K4813) & & $1: 2000$ \\
\hline
\end{tabular}

http://joe.endocrinology-journals.org DOI: 10.1530/JOE-14-0333
C 2014 Society for Endocrinology Printed in Great Britain
Published by Bioscientifica Ltd. 
number of PCNA-positive germ cells per ST was then calculated from the data obtained from each testis examined per group.

\section{Western blot/slot blot}

For immunoblot, $10 \%$ testicular homogenate was prepared. Equal amounts of proteins (50 g) determined by Lowry's method were loaded on SDS-PAGE (10\%) for electrophoresis (Lowry et al. 1951). The samples with equal amounts of protein were adjusted to equal volume with PBS and samples were loaded onto PVDF membrane using Millipore slot blot apparatus for slot blot analysis. Thereafter, proteins were transferred electrophoretically onto PVDF membrane (Sigma-Aldrich) overnight at $4{ }^{\circ} \mathrm{C}$ for western blot analysis. The transfer efficiency was checked by Ponceau S staining. PVDF membrane was then blocked for $1 \mathrm{~h}$ with TBS ( $\mathrm{pH} 7.6$ ) containing 5\% fat dry milk and then incubated with primary antiserum (see Table 1) for $1 \mathrm{~h}$ at room temperature or overnight at $4{ }^{\circ} \mathrm{C}$. Then, membranes were washed thrice for $10 \mathrm{~min}$ each in TBSTween 20. Immunodetection was performed with antirabbit IgG-conjugated HRP (1:1000) for $4 \mathrm{~h}$ and then washed in TBS for $10 \mathrm{~min}$ (three times). Signals were detected using an ECL Kit (Bio-Rad). Blot for each protein was repeated three times. The densitometric analysis of the immunoblots was performed by scanning and quantifying the bands for relative integrated density value (RIDV) using computer-assisted image analysis (Image $\mathrm{J} 1.48 \times, \mathrm{NIH})$. The data were normalized to $\beta$-actin levels and expressed relative to control as \% RIDV.

\section{3ß-HSD activity}

$3 \beta$-HSD activity was assayed according to Shivanandappa \& Venkatesh (1997) (35) using testicular homogenate. Tissue homogenate $(10 \%)$ was prepared in $0.1 \mathrm{M}$ Tris-HCl buffer ( $\mathrm{pH}$ 7.8). The homogenate was centrifuged at $12000 \boldsymbol{g}$ at
$4{ }^{\circ} \mathrm{C}$ and the supernatant was used as the source of enzyme. The enzyme was assayed in 0.1 M Tris- $\mathrm{HCl}$ buffer ( $\mathrm{pH} 7.8$ ) containing $500 \mathrm{mM}$ nicotinamide adenine dinucleotide sodium salt (NAD), $100 \mathrm{mM}$ DHEA as substrate and enzyme $(50 \mu \mathrm{l})$ in a total volume of $3.0 \mathrm{ml}$ and incubated at $37^{\circ} \mathrm{C}$ for $1 \mathrm{~h}$. The reaction was stopped by the addition of $2.0 \mathrm{ml}$ of phthalate buffer ( $\mathrm{pH}$ 3.0) and absorbance was measured at a wavelength of $490 \mathrm{~nm}$. The molar extinction coefficient calculated from standard graph is $0.0016 / \mathrm{M}$ per $\mathrm{cm}$. The enzyme activity was calculated from the standard curve of the reduced form of NADH (ranges from 0 to $150 \mathrm{nmol}$ ) and expressed as nanomoles of $\mathrm{NADH}$ formed per hour per milligram protein.

\section{Statistical analyses}

The densitometric data were presented as the mean of the percentage $\mathrm{RIDV} \pm$ s.E.M. The bands obtained from immunoblots were normalized to $\beta$-actin bands. The significance of the differences in testosterone levels and between groups was determined by one-way ANOVA followed by the Bonferroni's test using the SPSS Software 16 for window (Apache Software foundation) to compare the data from different groups. The significant differences for the count of immunoreactive germ cells were determined by one-way ANOVA followed by the Bonferroni's test. Data are expressed as mean \pm s.E.M. in the text. The data were considered significant if $P<0.05$.

\section{Results}

\section{Effect of RFRP3 treatment on testicular and white adipose tissue mass and GSI}

Changes in the testicular mass (mg) and GSI after the in vivo treatment with different doses of RFRP3 (0.02, 0.2 , and $2 \mu \mathrm{g} /$ day) for 8 days are given in Table 2 . Both the GSI and testicular mass decreased significantly

Table 2 Effect of RFRP3 treatment on body mass, testicular mass, GSI, and corrected count of germ cells. Values are expressed as mean \pm s.E.M. for five animals

\begin{tabular}{|c|c|c|c|c|c|c|c|}
\hline \multirow[b]{2}{*}{ Treatments } & \multirow[b]{2}{*}{$\begin{array}{c}\text { Body } \\
\text { mass }(g)\end{array}$} & \multirow[b]{2}{*}{$\begin{array}{l}\text { Testicular } \\
\text { mass (mg) }\end{array}$} & \multirow{2}{*}{$\begin{array}{c}\text { Gonado somatic } \\
\text { index/100 g BW } \\
(G S I / 100 \mathrm{~g} \mathrm{BW})\end{array}$} & \multicolumn{4}{|c|}{ Types of germ cells } \\
\hline & & & & Spermatogonia A & $\begin{array}{l}\text { Preleptotene } \\
\text { spermatocyte }\end{array}$ & $\begin{array}{c}\text { Pachytene } \\
\text { spermatocyte }\end{array}$ & $\begin{array}{c}\text { Step } 7 \\
\text { spermatids }\end{array}$ \\
\hline Control & $33.258 \pm 0.23$ & $104.89 \pm 3.46$ & $259.55 \pm 24.54$ & $0.97 \pm 0.03$ & $13.54 \pm 0.03$ & $17.09 \pm 0.71$ & $58.48 \pm 0.95$ \\
\hline RFRP3 $(0.02 \mu \mathrm{g})$ & $33.022 \pm 0.56$ & $110.246 \pm 0.63 *$ & $334.33 \pm 7.22 *$ & $0.89 \pm 0.03 *$ & $15.01 \pm 1.55^{*}$ & $17.27 \pm 1.85$ & $63.45 \pm 5.85$ \\
\hline RFRP3 $(0.2 \mu \mathrm{g})$ & $34.236 \pm 0.30$ & $91.23 \pm 1.78 *$ & $266.61 \pm 6.39 *$ & $0.87 \pm 0.08 *$ & $11.04 \pm 0.89 *$ & $10.18 \pm 1.42 *$ & $33.85 \pm 7.73 *$ \\
\hline RFRP3 $(2 \mu \mathrm{g})$ & $38.89 \pm 0.38 *$ & $84.404 \pm 0.68$ * & $217.06 \pm 1.58 *$ & $0.75 \pm 0.06 *$ & $17.80 \pm 1.70 *$ & $14.28 \pm 1.2 *$ & $37.22 \pm 5.43 *$ \\
\hline
\end{tabular}

Significantly different from controls $\left({ }^{*} P<0.05\right)$ by one-way ANOVA followed by the Bonferroni test.

http://joe.endocrinology-journals.org DOI: 10.1530/JOE-14-0333
(C) 2014 Society for Endocrinology Printed in Great Britain
Published by Bioscientifica Ltd 
$(P<0.05)$ in moderate $(0.2 \mu \mathrm{g} /$ day $)$ and high $(2 \mu \mathrm{g} /$ day $)$ dose when compared with control mice (Table 2). Mice treated with moderate and high doses of RFRP3 showed a significant $(P<0.05)$ increase in body mass due to increased accumulation of white adipose tissue (WAT) when compared with the control. Mice treated with moderate and high doses of RFRP3 showed, respectively, $2.88 \pm 0.08$ and $3.22 \pm 0.05 \mathrm{~g}$ of accumulated WAT when compared with $2.12 \pm 0.10 \mathrm{~g}$ of WAT in control mice.

Mice treated with a high $(2 \mu \mathrm{g} /$ day $)$ dose of RFRP3 showed a significant $(P<0.05)$ increase in body mass when compared with control mice. Treatment with RFRP3 caused no significant changes in the histology of liver and serum ALT and serum AST when compared with control mice.

\section{Effect of RFRP3 treatment in vivo on testicular histology and germ cell maturation}

The RFRP3-treated mice showed changes in testicular histology and development of germ cells (Table 2). The testis of control mice showed all stages of spermatogenesis (Fig. 1A and B). The treated mice showed abnormal histological changes in the STs. A low dose $(0.02 \mu \mathrm{g})$ of RFRP3 showed no remarkable changes (Fig. 1C, D and E), whereas moderate $(0.2 \mu \mathrm{g})$ and high doses $(2.0 \mu \mathrm{g})$ of RFRP3 showed degenerated nuclei in the germ cells, multinucleated giant cells (Fig. 1F, G and H), and condensation of chromatin in round spermatids and exfoliation of elongated spermatids within STs (Fig. 1I, J and $\mathrm{K}$ ) respectively. Mice treated in vivo showed a significant decrease in the number of SG A in a dosedependent manner, whereas low and high doses showed a significant increase in the number of Pl spermatocyte and a moderate dose showed a significant decrease in Pl spermatocyte. Mice treated with moderate and high doses of RFRP3 showed a significant decrease in the number of pachytene spermatocytes and type VII spermatids in the STs when compared with the control (Table 2).

\section{Effect of in vivo treatment of RFRP3 on steroidogenesis}

Serum testosterone levels of control and RFRP3 (low, moderate, or high dose)-treated mice are shown in Fig. 2. The different doses of RFRP3 showed a significant $(P<0.05)$ decrease in the testosterone level when compared with the control dose dependently. The RFRP3 treatment in vivo showed a significant $(P<0.05)$ decrease in testicular 3 $\beta$-HSD activity (Fig. 2) in a dose-dependent manner when comparison with the control.

All treatments with low, moderate, and high doses of RFRP3 showed dose-dependent decreases in the testicular expressions of STAR and P450scc proteins when compared with the control (Fig. 2C and D).

\section{Effect of in vivo treatment of RFRP3 on testicular expression of LHR and GNRHR proteins}

Densitometric analysis of Western blots showed dosedependent declines in the expressions of GNRHR and LHR proteins in the testis of RFRP3-treated mice when compared with control mice (Fig. 3A and B).

\section{Effect of in vivo treatment of RFRP3 on testicular expression of PCNA, BCL2, PARP, and caspase 3 proteins}

Immunolocalization of PCNA (Fig. 4) in adult testis of control mice showed that PCNA-positive cells were strongly detected in SG and early stage of spermatocytes during spermatogenic cycle based on morphological criteria and their characteristic pattern of association within the ST. The number of PCNA-positive germ cells per ST varies significantly from the control to the treated mice. The PCNA-positive cells per ST were found to be significantly higher in their number in the testis of control mice $(103.5 \pm 2.17)$ when compared with mice treated with high (60.45 \pm 4.79$)$, moderate $(28.45 \pm 4.21)$, and low $(34.8 \pm 3.29)$ doses of RFRP3 (Fig. 4).

Densitometric analysis of Western blots showed dose-dependent decreases in the expressions of PCNA, BCL2, and caspase 3 and PARP proteins in the testis of RFRP3-treated mice when compared with control mice (Fig. 5). Immunoblot of PCNA, BCL2, and active caspase 3 protein showed a single band at $\sim 36,26$, and $20 \mathrm{kDa}$, whereas that of PARP protein showed two immunoreactive bands at $\sim 116$ and $85 \mathrm{kDa}$. The immunoreactive band at $\sim 85 \mathrm{kDa}$ corresponds with the cleaved form of PARP. Densitometric analysis of Western blots also showed $(P<0.01)$ dosedependent decreases in the expressions of BCL2 and PCNA proteins significantly (Fig. 5A and B), whereas Western blots analysis showed $(P<0.01)$ dose-dependent increases in the expressions of caspase 3 and cleaved PARP significantly in the testis of RFRP3-treated mice when compared with control mice (Fig. 5C and D). However, RFRP3 treatment at all doses increased significantly $(P<0.01)$ the expressions of both whole and cleaved forms of PARP compared with control mice. (Fig. 5D).

Published by Bioscientifica Ltd. 

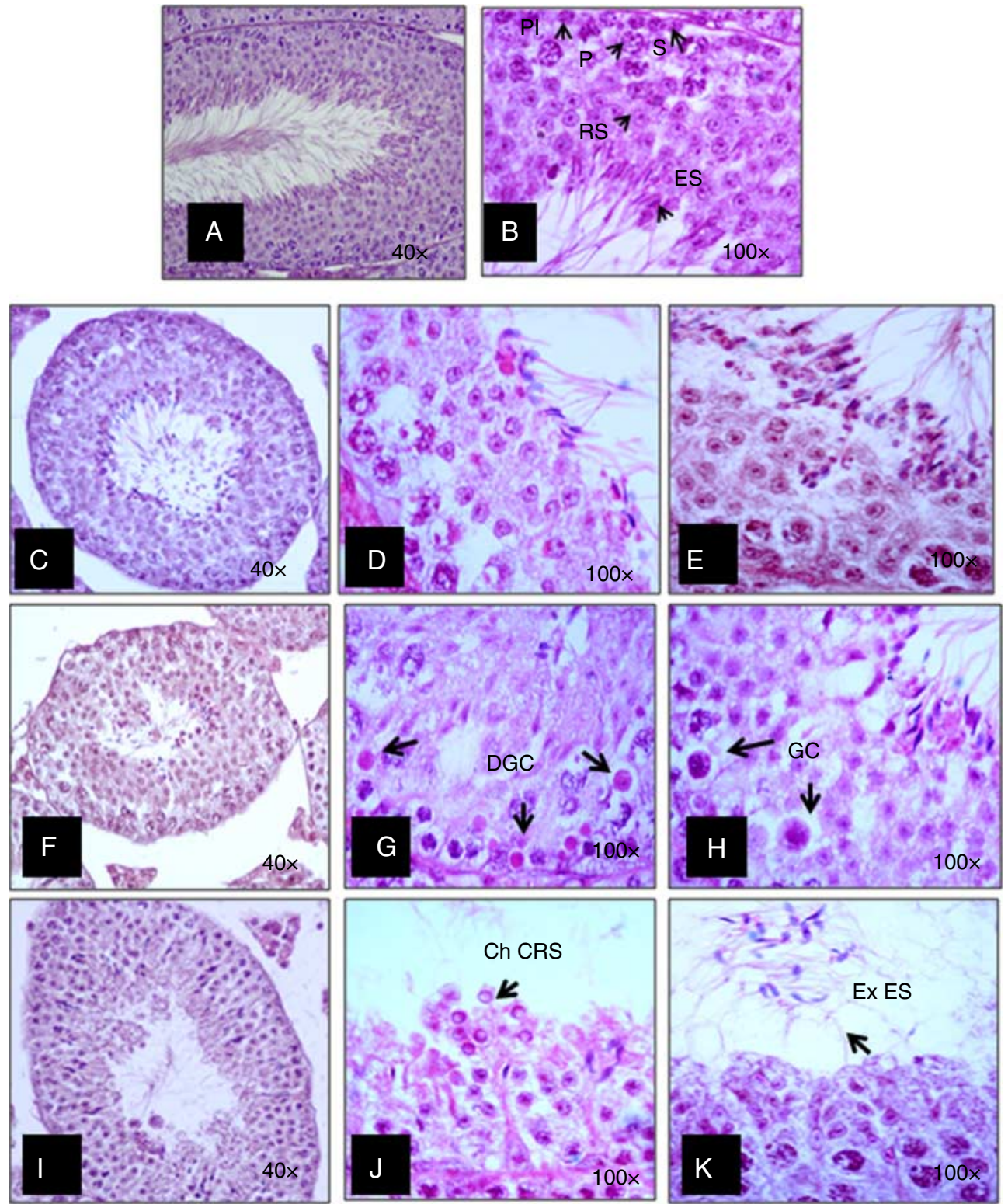

\section{Figure 1}

Light microscopic histological analysis of seminiferous tubules (STs) showing cellular alterations in different spermatogenic stages in control and treated mice. (A and B, stage VII) Control STs showed spermatogonia, preleptotene spermatocytes, pachytene spermatocytes round spermatids, and elongated spermatids. (C, D and E, stages VII and VIII) Low dose ( $0.02 \mu \mathrm{g}$ RFRP3) showed loosening of germinal epithelium in ST. (F, G and $H$, stage VIII) Moderate dose (0.2 $\mu \mathrm{g}$ RFRP3) showed giant cell and degenerating germ cell. (I, J and $\mathrm{K}$, stages VI and VIII) High dose

\section{Effect of in vitro treatment of RFRP3 with or without LH on testicular expression of STAR and LHR proteins and testosterone synthesis}

The testes treated with RFRP3 with or without LH in vitro showed significant $(P<0.05)$ variation in testosterone
( $2.0 \mu \mathrm{g}$ RFRP3) showed chromatin condensation in round spermatids and exfoliation of elongated spermatids in lumen. All the figures are shown in $40 \times$ and $100 \times$ magnification. Pl, preleptotene; $P$, pachytene; S, spermatogonia; RS, round spermatids; ES, elongated spermatids; DGC, degenerated germ cell; GC, giant cell; Ch CRS, chromatin condensation of round spermatids; Ex ES, exfoliation of elongated spermatids. Full colour version of this figure available via http://dx.doi.org/10.1530/JOE-14-0333.

synthesis. The testes treated in vitro with a high dose (10 ng/ml) of RFRP3 showed a significantly decreased level of testosterone, whereas the testes treated in vitro with $\mathrm{LH}$ alone (10 and $100 \mathrm{ng} / \mathrm{ml})$ or LH plus RFRP3 (100 ng/ml LH and $10 \mathrm{ng} / \mathrm{ml}$ RFRP3) showed a significant increase

Published by Bioscientifica Ltd. 


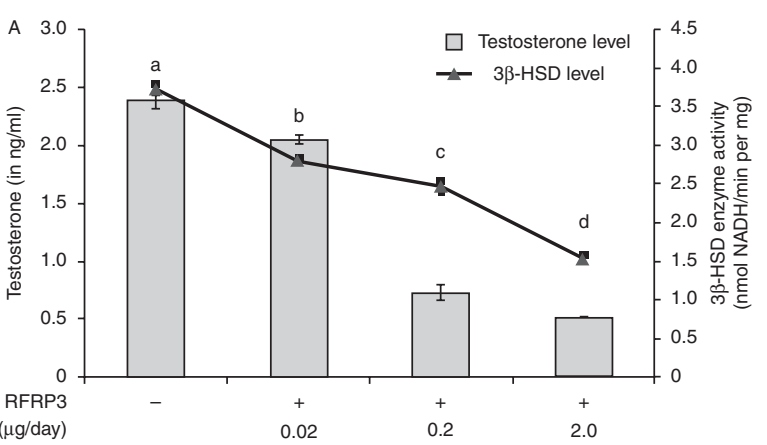

increase in the expression of STAR and LHR proteins when compared with the control (Fig. 6B and C).

\section{Effect of in vitro treatment of RFRP3 with or without LH on testicular expression of GNRH and GNRHR proteins}

The testes treated with RFRP3 with or without LH in vitro showed significant variations $(P<0.05)$ in the expressions
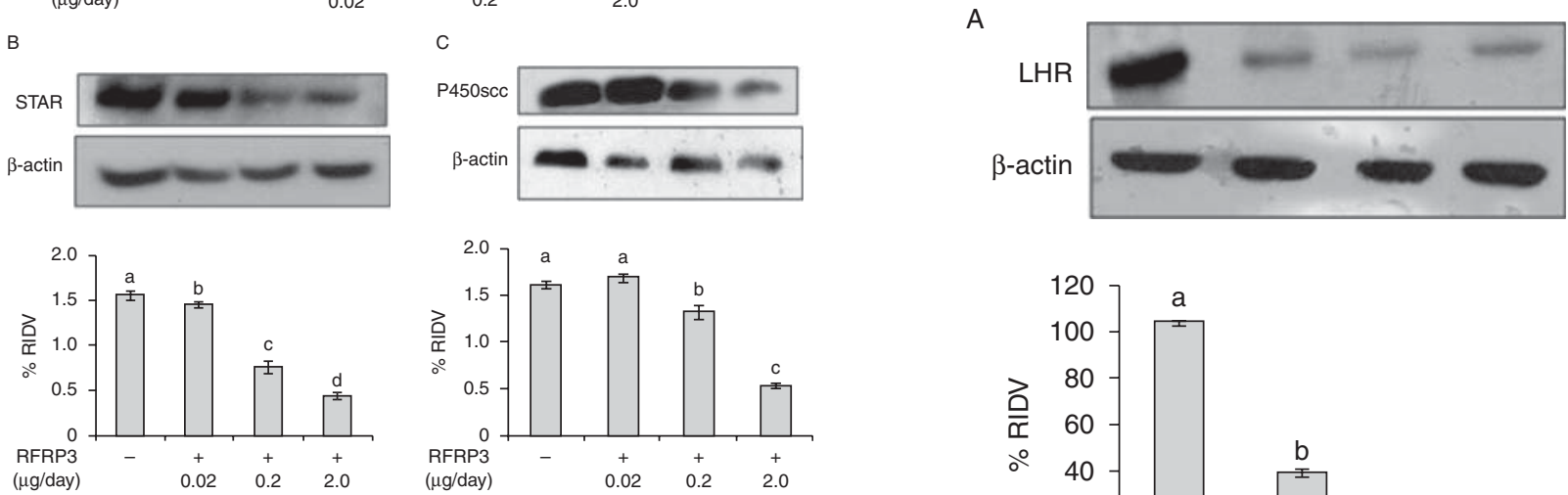

Figure 2

(A) Changes in the serum testosterone level in RFRP3-treated mice showed a significant decrease in the circulating testosterone level with different doses (low dose $=0.02 \mu \mathrm{g} ; \mathrm{b}, P<0.05$ : moderate dose $=0.2 \mu \mathrm{g} ; \mathrm{c}, P<0.05$, and high dose $=2.0 \mu \mathrm{g} /$ day; $d, P<0.05)$ of RFRP3 when compared with the control $(a, P<0.05)$. Changes in testicular $3 \beta$-hydroxysteroid dehydrogenase (3 $\beta-H S D)$ enzyme activity in treated mice showed a significant decrease in 3 $\beta$-HSD enzyme activity with different doses (low dose $=$ $0.02 \mu \mathrm{g} ; \mathrm{b}, P<0.05$ : moderate dose $=0.2 \mu \mathrm{g} ; \mathrm{c}, P<0.05$, and high dose $=$ $2.0 \mu \mathrm{g} /$ day; $\mathrm{d}, P<0.05)$ of RFRP3 when compared with the control $(a, P<0.05)$. Values are expressed as means \pm s.E.M. Different letters indicate a significant difference at $P<0.05$. (B) The densitometric analysis of the immunoblot of testicular STAR protein in mice treated with different doses of RFRP3 (low dose $=0.02 \mu \mathrm{g} ; \mathrm{b}, P<0.05$ : moderate dose $=0.2 \mu \mathrm{g}, c, P<0.05$, and high dose $=2.0 \mu \mathrm{g} / \mathrm{day}, \mathrm{d}, P<0.05)$ showed a significant decrease in the expression of testicular STAR protein when compared with the control $(a, P<0.05)$ and (C). P450scc proteins in mice treated with different doses of RFRP3 (moderate dose $=0.2 \mu \mathrm{g} ; \mathrm{b}, P<0.05$ and high dose $=2.0 \mu \mathrm{g} /$ day; $\mathrm{d}, P<0.05)$ showed significant decreases in the expressions of P450scc proteins when compared with the control $(a, P<0.05)$ and low dose of RFRP3 $(0.02 \mu \mathrm{g} ; \mathrm{a}, P<0.05)$. Values are expressed as means \pm s.E.M. Different letters indicate a significant difference at $P<0.05$.

$(P<0.05)$ in the testosterone level when compared with the control (Fig. 6A). The testes treated in vitro with LH plus RFRP3 showed a significant increase $(P<0.05)$ in the testosterone level when compared with the LH alone. Densitometry analysis of Western blots showed significant decreases $(P<0.05)$ in the testicular expressions of STAR and LHR proteins following the treatment with a high dose $(10 \mathrm{ng} / \mathrm{ml})$ of RFRP3, whereas the testes treated in vitro with LH alone (10 and $100 \mathrm{ng} / \mathrm{ml})$ or LH plus RFRP3 $(100 \mathrm{ng} / \mathrm{ml}$ LH and $10 \mathrm{ng} / \mathrm{ml}$ RFRP3) showed a significant $(P<0.05)$
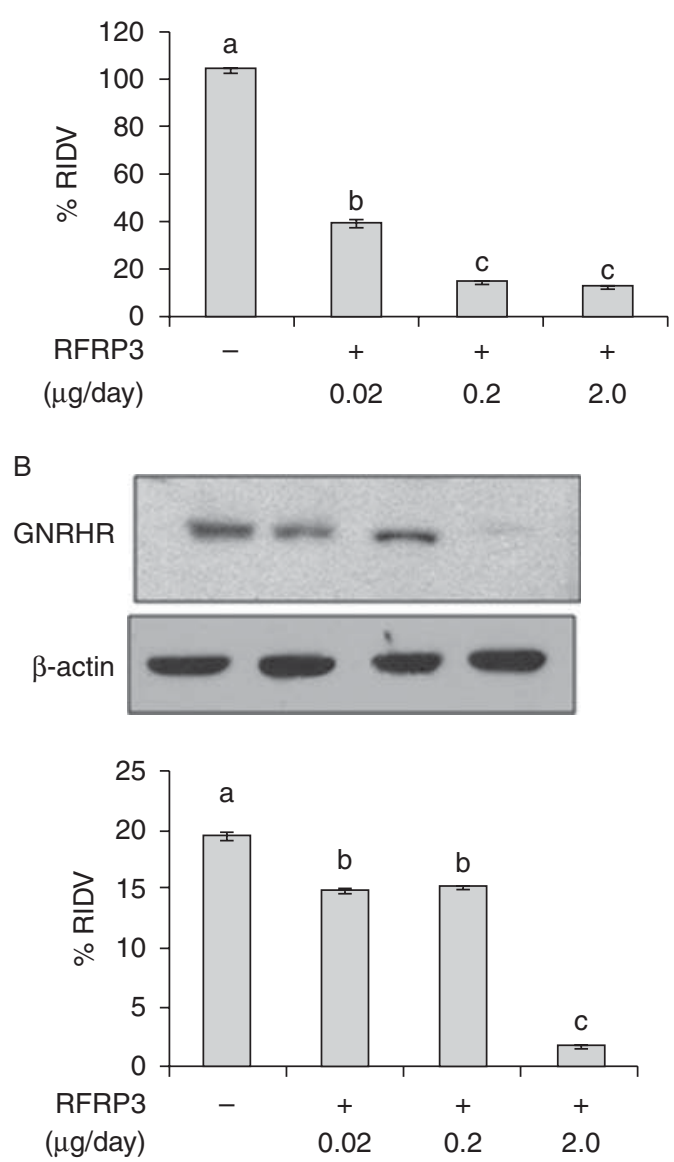

Figure 3

(A) The densitometric analysis of the immunoblot of testicular LHR protein in mice treated with different doses of RFRP3 (low dose $=0.02 \mu \mathrm{g}$; b, $P<0.05$ : moderate dose $=0.2 \mu \mathrm{g} ; \mathrm{c}, P<0.05$, and high dose $=2.0 \mu \mathrm{g} / \mathrm{day}$; $C, P<0.05)$ showed a significant decrease in LHR when compared with the control $(a, P<0.05)$. (B) The immunoblot of testicular GNRHR protein in mice treated with different doses of RFRP3 (low dose $=0.02 \mu \mathrm{g}$, moderate dose $=0.2 \mu \mathrm{g}$, and high dose $=2.0 \mu \mathrm{g} / \mathrm{day}$ ) showed a significant decrease in the expression of GNRHR protein in low, moderate $(b, P<0.05)$, and high doses of RFRP3 $(c, P<0.05)$ when compared with the control $(a, P<0.05)$. 

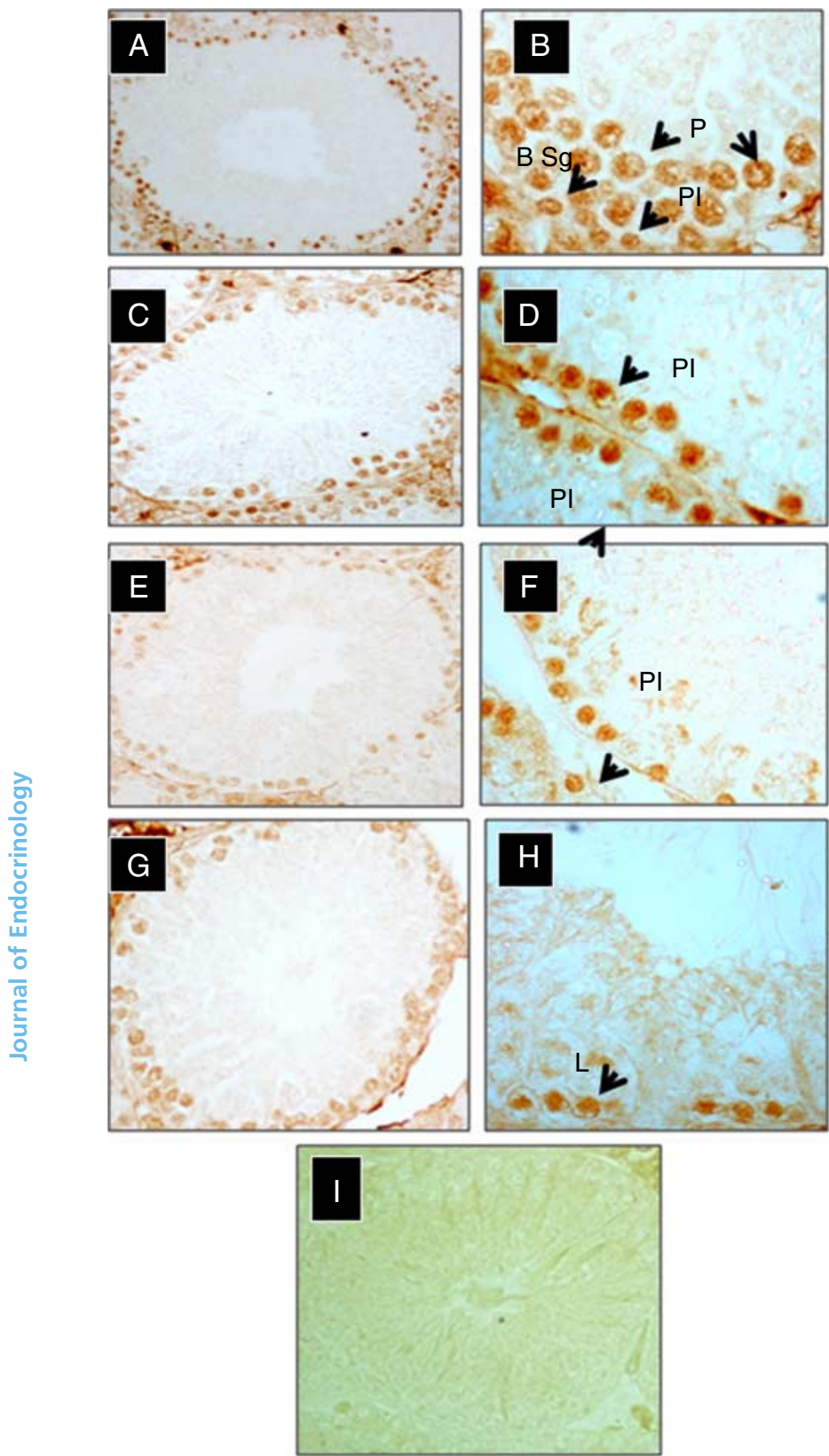

\section{Figure 4}

Immunohistochemical localization of proliferating cell nuclear antigen (PCNA) in the testis with different doses of RFRP3 (low dose $=0.02 \mu \mathrm{g}$, moderate dose $=0.2 \mu \mathrm{g}$, and high dose $=2.0 \mu \mathrm{g} / \mathrm{day}$ ). (A and B) In controls, PCNA-positive cells were strongly detected in spermatogonia and earlystage spermatocyte (mainly in the spermatogonia B (B Sg), preleptotene ( $p l$ $\mathrm{Sc}) /$ leptotene (L), and pachytene (P SC) stage) of the spermatogenic cycle in mice. Mice treated with different doses, i.e. low dose ( $C$ and $D)$, moderate dose (E and F), and high dose (G and H), of RFRP3 showed low PCNApositive staining in germinal cell when compared with the control. Negative control for PCNA protein was shown (I). Arrowhead indicates spermatogonia and early-stage spermatocytes. All the figures are shown in $40 \times$ and $100 \times$ magnification. Full colour version of this figure available via http://dx.doi.org/10.1530/JOE-14-0333. of GNRH and GNRHR. The testes treated with the two different doses of RFRP3 alone showed dose-dependent decreases in the expressions of both GNRH and GNRHR proteins. Different doses of LH treatment also caused significant decreases in the expressions of both GNRH and GNRHR proteins. Interestingly, the testes treated with RFRP3 with LH in vitro showed significant increases $(P<0.05)$ in the expressions of GNRH and GNRHR proteins (Fig. 7A and B).
A
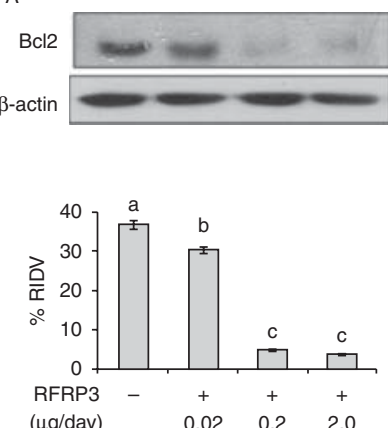

c
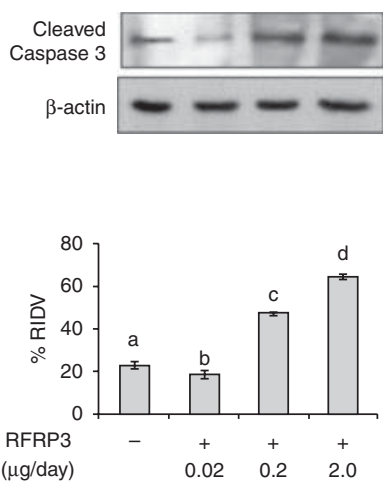
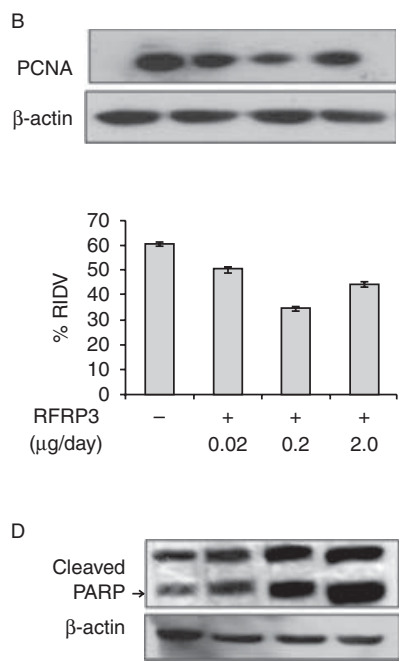

$\square$ Whole PARP

$\square$ Cleaved PARP

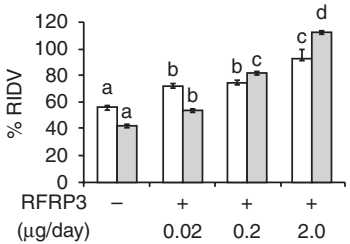

\section{Figure 5}

The densitometric analysis of the immunoblot of BCL2 protein in mice treated with different doses of RFRP3 (low dose $=0.02 \mu \mathrm{g} ; \mathrm{b}, P<0.05$ : moderate dose $=0.2 \mu \mathrm{g} ; c, P<0.05$, and high dose $=2.0 \mu \mathrm{g} / \mathrm{day} ; c, P<0.05$ ) showed a significant decrease in the expression of BCL2 when compared with the control $(a, P<0.05)(A)$. The immunoblot of PCNA protein in mice treated with different doses of RFRP3 (low dose $=0.02 \mu \mathrm{g} ; \mathrm{b}, P<0.05$ : moderate dose $=0.2 \mu \mathrm{g} ; \mathrm{c}, P<0.05$, and high dose $=2.0 \mu \mathrm{g} / \mathrm{day} ; \mathrm{d}, P<0.05$ ) showed a significant decrease in the expression of PCNA when compared with the control $(a, P<0.05)(B)$. The immunoblot of caspase 3 protein in mice treated with different doses of RFRP3 (low dose $=0.02 \mu \mathrm{g} ; \mathrm{b}, P<0.05$ : moderate dose $=0.2 \mu \mathrm{g} ; \mathrm{c}, P<0.05$, and high dose $=2.0 \mu \mathrm{g} / \mathrm{day} ; \mathrm{d}, P<0.05$ ) showed a significant increase in the expression of Caspase 3 when compared with the control $(a, P<0.05)$ (C). The immunoblot of PARP protein in mice treated with different doses of RFRP3 (low dose $=0.02 \mu \mathrm{g}$; b, $P<0.05$ : moderate dose $=0.2 \mu \mathrm{g} ; \mathrm{c}, P<0.05$, and high dose $=2.0 \mu \mathrm{g} / \mathrm{day}$; $\mathrm{d}, P<0.05)$ when compared with the control $(\mathrm{a}, P<0.05)$ in mice $(D)$. Values are expressed as means \pm S.E.M. Different letters indicate a significant difference at $P<0.05$.

Published by Bioscientifica Ltd. 


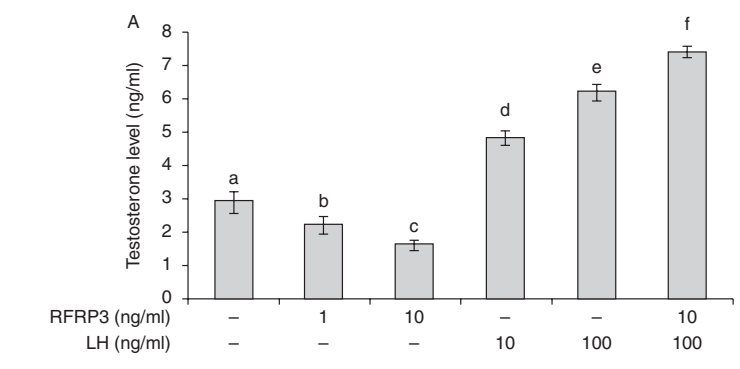

B

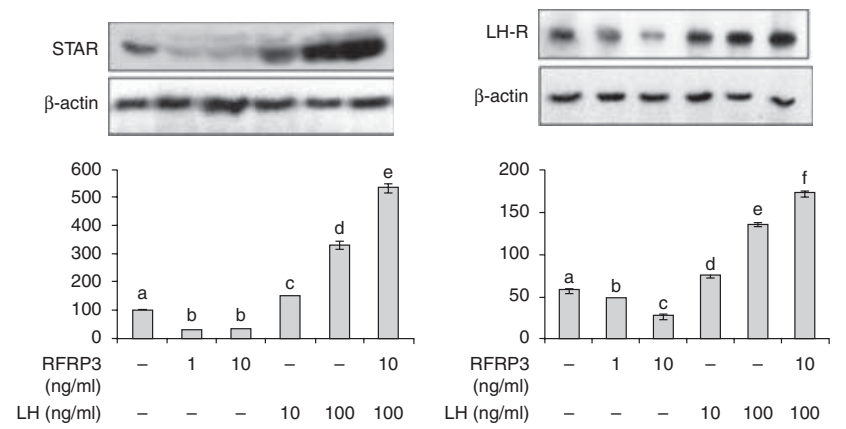

Figure 6

Changes in testosterone level in media with different doses of RFRP-3 (low $=1 \mathrm{ng} / \mathrm{ml}$ and high dose $=10 \mathrm{ng} / \mathrm{ml}$ ) with or without LH (low dose $=10$ $\mathrm{ng} / \mathrm{ml}$ and high dose $=100 \mathrm{ng} / \mathrm{ml}$ ) showed a significant decrease in the testosterone level in both dose of RFRP-3 ( $b$ and $c, P<0.05$ ) vs control $(a, P<0.05)$ and significantly increased in the testosterone level in both doses of LH ( $\mathrm{d}$ and e, $P<0.05$ ) vs control $(\mathrm{a}, P<0.05)$, whereas, high dose of LH together with high dose of RFRP-3 showed a remarkable significant $(f, P<0.05)$ increase in testosterone level vs control $(a, P<0.05)(A)$. Immunoblot analysis of an in vitro treatment of RFRP-3 (low dose $=1 \mathrm{ng} / \mathrm{ml}$ and high dose $=10 \mathrm{ng} / \mathrm{ml}$ ) with or without $\mathrm{LH}$ (low dose $=10 \mathrm{ng} / \mathrm{ml}$ and high dose $=100 \mathrm{ng} / \mathrm{ml}$ ) showed a significantly decrease in the expression of StAR protein in both doses of RFRP-3 $(b, P<0.001)$ vs control $(a, P<0.001)$ and both doses of $\mathrm{LH}$ alone showed a significant increased the expression StAR protein ( $c$ and $d, P<0.001)$ vs control $(a, P<0.001)$, whereas, high dose of RFRP-3 with high dose of LH showed a significant $(e, P<0.001)$ increase the expression of StAR protein vs control $(a, P<0.001)(B)$. Immunoblot analysis of an in vitro treatment of RFRP-3 (low dose $=1 \mathrm{ng} / \mathrm{ml}$ and high dose $=10 \mathrm{ng} / \mathrm{ml}$ ) with or without $\mathrm{LH}$ (low dose $=10 \mathrm{ng} / \mathrm{ml}$ and high dose $=$ $100 \mathrm{ng} / \mathrm{ml}$ ) showed a significant decrease in the expression of LH-R protein with both doses of RFRP-3 ( $b$ and $c, P<0.05$ ) vs control $(a, P<0.05)$ and both the doses of $\mathrm{LH}$ alone showed a significant increased the expression LH-R protein ( $d$ and e, $P<0.05)$ vs control $(a, P<0.05)$, whereas, high dose of RFRP-3 with high dose of LH showed a significant $(e, P<0.05)$ increase the expression of LH-R protein vs control $(a, P<0.05)(C)$. Values are the means \pm SEM. Different letters indicate a significant difference at $P<0.05$.

\section{Discussion}

The major findings of this study are that RFRP3 treatment to adult mice caused regressive changes in testicular spermatogenesis. The regressing changes are mainly due to significant decreases in cell proliferation and survival markers, such as PCNA and Bcl2, and increases in apoptotic markers, such as caspase 3 and PARP proteins, in the testis. RFRP3 treatment also inhibited the testicular steroidogenesis mainly by inhibiting LHR together with steroidogenic factors, such as StAR and steroidogenic enzymes, P450scc and 3 $\beta$-HSD. The testes treated with RFRP3 in vitro also showed a significant decline in testosterone secretion, suggesting a direct inhibitory action of RFRP3 in the testis of mice. The testicular expressions of RFRP3 and its receptor, GPR147, have recently been demonstrated in the STs of Syrian hamster (Zhao et al. 2010) and rhesus monkeys (Ubuka et al. 2009a).

In this study, the high dose of RFRP3 treatment for 8 days significantly increased the body mass of mice. This gain in body mass was as a result of accumulation of WAT in the abdominal cavity. A similar accumulation of fat has previously been demonstrated in response to GnIH treatment in female mice (Singh et al. 2011a,b). The mechanism by which RFRP3/GnIH increases food intake seems to be similar to that of NPY (Clark et al. 1984).

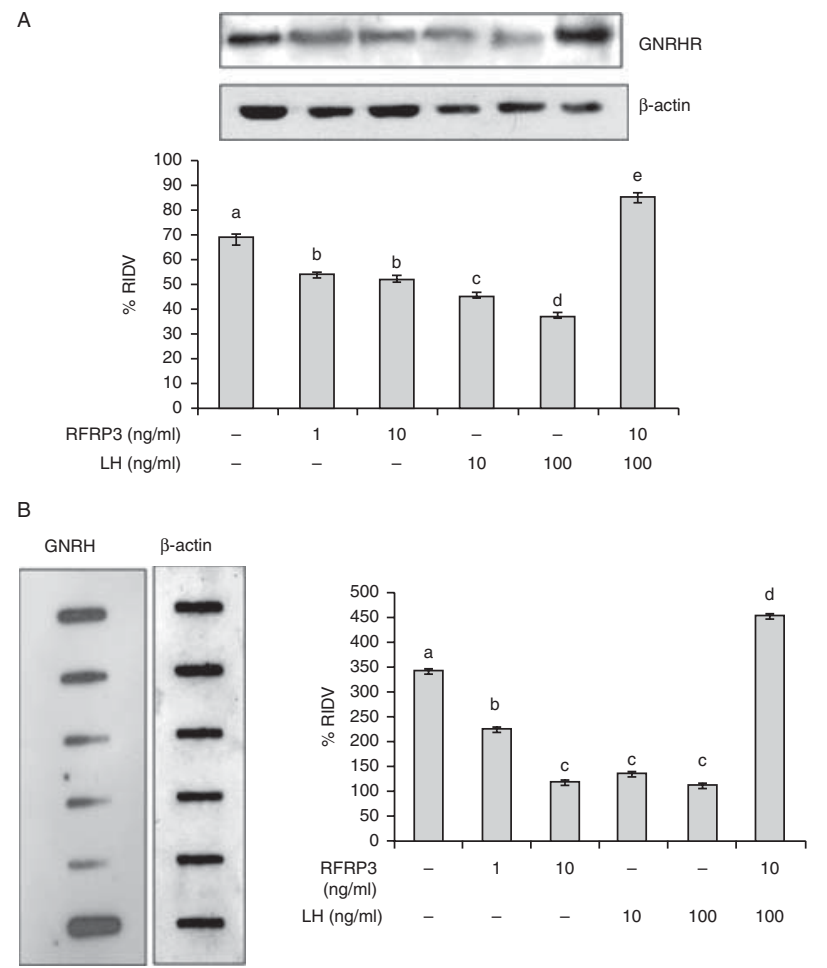

Figure 7

Western blot/slot blot analysis of in vitro treatment of RFRP3 (low dose $=$ $1 \mathrm{ng} / \mathrm{ml}$ and high dose $=10 \mathrm{ng} / \mathrm{ml}$ ) with or without $\mathrm{LH}$ (low dose $=10 \mathrm{ng} / \mathrm{ml}$ and high dose $=100 \mathrm{ng} / \mathrm{ml}$ ) showed significant decreases in the expressions of GNRHR (A) and GNRH (B) proteins at both doses of RFRP3 (b, $P<0.05$ ) when compared with the control $(a, P<0.05)$, both doses of $\mathrm{LH}$ alone showed a significant decrease in the expression of GNRHR protein ( $c$ and $d$, $P<0.05)$ when compared with the control $(a, P<0.05)$, whereas a high dose of RFRP3 with a high dose of LH showed significant $(e, P<0.05)$ increases in the expressions of GNRHR and GNRH proteins when compared with the control $(a, P<0.05)$. Values are expressed as means \pm s.E.M. Different letters indicate a significant difference at $P<0.05$.

Published by Bioscientifica Ltd. 
The results from this study showed a dose-dependent regressing effect of RFRP3 treatment on the histological feature of the ST of mice testes. Spermatogenic impairment is characterized by dose-dependent decreases in germ cell proliferation (PCNA) and survival (Bcl2) marker. PCNApositive cells were detected in SG and early phase of primary spermatocytes, regardless of the stage of the STs. This is in agreement with the previous study, demonstrating that the PCNA reactivity was expressed in SG and early phase of primary spermatocytes in all stages of the STs (Kang et al. 1997). BCL2 is a pro-survival (antiapoptotic) protein and showed a positive relationship with the spermatogenic activity (Banerjee et al. 2012). In this study, RFRP3-treated mice showed statistically significant differences in the DNA damage repair marker, PARP, and apoptosis markers, caspase 3 and cleaved PARP. Interestingly, the high dose of RFRP3 showed chromatin condensation of round spermatids and significantly increased the expressions of cleaved PARP and caspase 3 proteins. This study supports by the previous study, where the PARP pathway plays multipurpose roles of biological processes including DNA repair, apoptosis, and necrosis (Burkle 2005). PARP enzymes are believed to be activated by DNA strand breaks, and DNA breakage is linked to chromatin compaction, which occurs in differentiating spermatids as the tightly compact chromatin during spermatogenesis (McPherson \& Longo 1992, 1993, Smith \& Haaf 1998, Marcon \& Boissonneault 2004). Similarly in a previous study, GnIH administration induced testicular apoptosis and decreased spermatogenic activity in birds (Ubuka et al. 2006). It is likely that apoptotic cell death in the testis is a result of the GnIH-induced decrease in testicular testosterone synthesis (Ubuka et al. 2006). In this study, spermatogenic cycle of the treated mice is characterized by the abolition of round spermatids beyond stage VII, with the numbers of spermatocytes being severely reduced (Table 1). A recent study has demonstrated the presence of RFRP3 and its receptor in the ST and the expression of RFRP3 increased in germ cells of stages VII-XII, late spermatocytes, and early round spermatids in Syrian hamsters (Zhao et al. 2010). Thus, a previous study together with the present findings suggests that RFRP3 might be involved in the final maturation of spermatids in the spermatogenic cycle (Zhao et al. 2010).

The present results also point out that the inhibitory effect of RFRP3 on the spermatogenic cycle might be due to the suppressive effects of RFRP3 on synthesis and action of testicular GnRH. A similar suppressive spermatogenic activity was earlier noticed in the rat or mice immunized against GnRH or treated with GnRH antagonists (Cook et al. 2000). The present in vitro study showed dose-dependent decreases in the concentrations of both GNRH and GNRHR proteins with RFRP3 treatment in the testis. Interestingly, either RFRP3 or LH alone has the inhibitory effect on testicular activity, but LH together with RFRP3 has stimulatory effects on the expressions of both GNRH and GNRHR proteins. We also reported that the treatment with $\mathrm{GnIH}$ causes a significant decrease in GnRHR levels resulting in regressive changes in the testis of mice (Anjum et al. 2012). Thus, GnIH/RFRP3 together with GnRH is a part of the complex system of gonadal regulation.

The results of both in vitro and in vivo analyses suggest a direct effect of RFRP3 on testicular steroidogenesis in mice. Treatments with different doses of RFRP3, both in vivo and in vitro, showed a significant decrease in testosterone synthesis in the testis of mice. RFRP3 affected steroidogenesis by inhibiting dose-dependent expressions of various steroidogenic factors, such as STAR, P450scc, and 33-HSD proteins. RFRP3 may also influence steroidogenesis by severely suppressing the testicular expression of the LHR protein. These findings support the previous finding on avian gonads showing the presence of GnIHR on Leydig cells (Bentley et al. 2008). The present and previous findings thus suggest that RFRP3 has the direct inhibitory effect on the steroidogenic activity of Leydig cells.

The in vitro treatment of RFRP3 caused a significant decline in testosterone secretion together with a decrease in the testicular expression of STAR and LHR proteins, whereas treatment of RFRP3 plus LH resulted in increased secretion of testosterone together with increased expression of STAR and LHR proteins. These findings suggest that RFRP3 alone is inhibitory, but RFRP3 in presence of LH is stimulatory to testicular activities. In both in vivo and in vitro studies, RFRP3 treatment caused a marked decline in the concentration of testicular GnRHR, which coincides with the significant decline in the circulating testosterone level. This finding suggests that RFRP3 suppresses testicular activity by regulating the local GnRH system. This finding also supports our previous finding suggesting that the decline in reproductive activity during senescence could be due to the increase in GnIH-induced decline in GnRHR in the testis (Anjum et al. 2012). Interestingly, in this study, the treatment with LH alone downregulated GnRHR, but RFRP3 together with LH upregulated GnRHR. The reason for such a differential effect of LH on GnRHR is unknown and requires further confirmation. Testes are the site of synthesis and action of many neuropeptides, including GnRH and GnIH/RFRPs (Anjum et al. 2012). The physiological action of many of these neuropeptides including GnRH has mainly been studied in isolation. Whether these neuropeptides interact with each other during regulation of various testicular activities requires

Published by Bioscientifica Ltd. 
further investigation. This study suggests that RFRP3 is an important intratesticular factor inhibiting spermatogenesis and steroidogenesis in the testis of mice. The inhibition of testicular activities induced by RFRP3 is not a result of generalized toxicity, as even a higher dose of RFRP3 caused no deleterious effects on the histology of liver and serum AST and ALT activity compared with control mice. The antigonadal function of GnIH/RFRP3 was demonstrated previously in male quail (Ubuka et al. 2006, 2014), Syrian Hamster (Zhao et al. 2010), and female mice (Singh et al. 2011b).

This study further showed a significant decrease in the survival factor (Bcl2) level but a significant increase in the cleaved PARP level in RFRP3-treated mice compared with untreated control. This might be due to degenerative changes in the germ cells as was also observed in the histological sections of the testis of treated mice. Until date, only limited information is available regarding the intracellular signal transduction pathways by which RFRP3 exerts its effect on gonadal activities. Previous studies identified the two G protein-coupled receptors, GPR147 and GPR74 for GnIH/RFRP3 (Yin et al. 2005, Gibson et al. 2008, Zhao et al. 2010). Both the receptors are capable of inhibiting forskolin-stimulated cyclic adenosine monophosphate accumulation, suggesting an activation of Gi/o subunit of $G$ protein (Zhao et al. 2010). This study together with the previous study suggests antigonadal effects of RFRP3 both by inhibiting gonadotropin release as well as by inducing apoptotic changes in the testis by paracrine/autocrine mechanism.

In brief, this study provides evidence suggesting that RFRP3 acts on the testis of mice and suppresses spermatogenesis and steroid synthesis. The RFRP3 treatment in vivo showed dose-dependent regressive changes in the histological features, such as decline in germ cell proliferation and survival marker, whereas increase in germ cell apoptosis. Both in vivo and in vitro studies showed an inhibitory effect of RFRP3 on testicular synthesis of testosterone. RFRP3 affected steroidogenesis by inhibiting dose-dependent expressions of steroidogenic factors, such as LHR, STAR, P450scc, and 3 $\beta$ HSD. This study also demonstrated that the inhibitory effect of RFRP3 ( 1 and $10 \mathrm{ng} / \mathrm{ml}$ ) in the testis may be mediated through local production of GnRH. Thus, RFRP3 was acting either indirectly through GnRH or directly on the testis of mice and influenced germ cell proliferation, survival, and apoptosis and steroidogenesis.

\section{Declaration of interest}

The authors declare that there is no conflict of interest that could be perceived as prejudicing the impartiality of the research reported.

\section{Funding}

This work was supported in part by a grant-in-aid from the UGC, New Delhi, to $A K$ and $S A$ highly acknowledges the financial assistance from the RFSMS-UGC, New Delhi.

\section{References}

Abercrombie M 1946 Estimation of nuclear population from microtome sections. Anatomical Record 94 239. (doi:10.1002/ar.1090940210)

Anjum S \& Krishna A 2012 Effect of gonadotropin-inhibitory hormone on testicular activities in adult male mouse. In National Conference and 30th Annual Symposium of the Society for Reproductive Biology and Comparative Endocrinology (SRBCE) on Novel Aspect and Emerging Trends in Reproduction and Endocrinology, PP2 75-76 (Abstract). Udaipur, India: Mohanlal Sukhadia University.

Anjum S, Krishna A, Sridaran R \& Tsutsui K 2012 Localization of gonadotropin-releasing hormone $(\mathrm{GnRH})$, gonadotropin-inhibitory hormone $(\mathrm{GnIH})$, kisspeptin and GnRH-receptor and their possible roles in testicular activities from birth to senescence in mice. Journal of Experimental Zoology 317A 630-644. (doi:10.1002/jez.1765)

Banerjee A, Anjum S, Verma R \& Krishna A 2012 Alteration in expression of estrogen receptor alpha and beta, and aromatase in the testis and its relation with changes in nitric oxide during aging in mice. Steroid $\mathbf{7 7}$ 609-620. (doi:10.1016/j.steroids.2012.02.004)

Bentley GE, Kriegsfeld LJ, Osugi T, Ukena K, O’Brien S, Perfito N, Moore IT, Tsutsui K \& Wingfield JC 2006 Review Interactions of gonadotropinreleasing hormone $(\mathrm{GnRH})$ and gonadotropin-inhibitory hormone $(\mathrm{GnIH})$ in birds and mammals. Journal of Experimental Zoology. Part A, Comparative Experimental Biology 305(9) 807-814. (doi:10.1002/jez.a.306)

Bentley GE, Ubuka T, McGuire NL, Chowdhury VS, Morita Y, Yano T, Hasunuma I, Binns M, Wingfield JC \& Tsutsui K 2008 Gonadotropininhibitory hormone and its receptor in the avian reproductive system. General and Comparative Endocrinology 156 34-43.

Burkle A 2005 Poly(ADP-ribose). The most elaborate metabolite of NAD+. FEBS Journal 272 4576-4589. (doi:10.1111/j.1742-4658.2005.04864.x)

Clark JT, Kalra PS, Crowley WR \& Kalra SP 1984 NPY and human pancreatic polypeptide stimulate feeding behavior in rats. Endocrinology $\mathbf{1 1 5}$ 427-429 (doi:10.1210/endo-115-1-427).

Cook RB, Popp JD, Kastelic JP, Robbins S \& Harland R 2000 The effects of active immunization against $\mathrm{GnRH}$ on testicular development, feedlot performance, and carcass characteristics of beef bulls. Journal of Animal Science $\mathbf{7 8}$ 2778-2783.

Fukusumi S, Habata Y, Yoshida H, Iijima N, Kawamata Y \& Hosoya M 2001 Characteristics and distribution of endogenous RFamide-related peptide-1. Biochimica et Biophysica Acta 1540 221-232. (doi:10.1016/ S0167-4889(01)00135-5)

Gibson EM, Humber SA, Jain S, Williams Zh III WP, ao S, Bentley GE, Tsutsui K \& Kriegsfeld LJ 2008 Alterations in RFamide-related peptide expression are coordinated with the preovulatory luteinizing hormone surge. Endocrinology 149 4958-4969. (doi:10.1210/en.2008-0316)

Hinuma S, Shintani Y, Fukusumi S, Iijima N, Matsumoto Y, Hosoya M, Fujii R, Watanabe T, Kikuchi K, Terao Y et al. 2000 New neuropeptides containing carboxy-terminal RFamide and their receptor in mammals. Nature Cell Biology 2 703-708. (doi:10.1038/35036326)

Hsueh AJW \& Schaeffer JM 1985 Gonadotropin releasing hormone as paracrine hormone and neurotransmitter in extrapituitary sites. Journal of Steroid Biochemistry 23 757-764. (doi:10.1016/S00224731(85)80011-X)

Johnson MA, Tsutsui K \& Fraley GS 2007 Rat RFamide related peptide-3 stimulates GH secretion, inhibits LH secretion, and has a variable effect on sex behavior in the adult male rat. Hormones and Behavior $\mathbf{5 1}$ 171-180. (doi:10.1016/j.yhbeh.2006.09.009)

Kang MJ, Kim MK, Terhune A, Park JK, Kim YH \& Koh GY 1997 Cytoplasmic localization of cyclin D3 in seminiferous tubules during

Published by Bioscientifica Ltd. 
testicular development. Experimental Cell Research 234 27-36. (doi:10 1006/excr.1997.3590)

Kriegsfeld LJ, Mei DF, Bentley GE, Ubuka T, Mason AO, Inoue K, Ukena K, Tsutsui K \& Silver R 2006 Identification and characterization of a gonadotropin-inhibitory system in the brains of mammals. PNAS $\mathbf{1 0 3}$ 2410-2415. (doi:10.1073/pnas.0511003103)

Leblond CP \& Clermont Y 1952 Definition of the stages of the cycle of the seminiferous epithelium in rat. Annals of the New York Academy of Sciences 55 548-573. (doi:10.1111/j.1749-6632.1952.tb26576.x)

Lowry OH, Rosebrough NJ, Farr AL \& Randall RJ 1951 Protein measurement with the folin phenol reagent. Journal of Biological Chemistry 193 265-275.

Marcon L \& Boissonneault G 2004 Transient DNA strand breaks during mouse and human spermiogenesis new insights in stage specificity and link to chromatin remodeling. Biology of Reproduction 70 910-1008. (doi:10.1095/biolreprod.103.022541)

McGuire NL \& Bentley GE 2010 A functional neuropeptide system in vertebrate gonads: gonadotropin-inhibitory hormone and its receptor in testes of field-caught house sparrow (Passer domesticus). General and Comparative Endocrinology 166 565-572. (doi:10.1016/j.ygcen. 2010.01.010)

McPherson S \& Longo FJ 1992 Localization of DNAase I-hypersensitive regions during rat spermatogensis: stage dependent pattern and unique sensitivity of elongated spermatids. Molecular Reproduction and Development 31 268-279. (doi:10.1002/mrd.1080310408)

McPherson S \& Longo FJ 1993 Chromatin structure-function alteration during mammalian spermatogenesis: DNA nicking and repair in elongating spermatids. European Journal of Histochemistry 37 109-128.

Russell LD, Ren HP, Sinha Hikim I, Schultz W \& Sinha Hikim AP 1990 A comparative study in twelve mammalian species of volume densities, volumes, and numerical densities of selected testis components, emphasizing those related to the Sertoli cell. American Journal of Anatomy 188 21-30.

Satake H, Hisada M, Kawada T, Minakata H, Ukena K \& Tsutsui K 2001 Characterization of a cDNA encoding a novel avian hypothalamic neuropeptide exerting an inhibitory effect on gonadotropin release. Biochemical Journal 354 379-385. (doi:10.1042/0264-6021:3540379)

Shivanandappa T \& Venkatesh S 1997 A colorimetric assay method for 3betahydroxy-delta5-steroid dehydrogenase. Analytical Biochemistry 254 57-61. (doi:10.1006/abio.1997.2406)

Singh P, Krishna A, Sridaran R \& Tsutsui K 2011a Immunohistochemical localization of GnRH and RFamide-related peptide- 3 in the ovaries of mice during the estrous cycle. Journal of Molecular Histology 42 371-381. (doi:10.1007/s10735-011-9340-8)

Singh P, Krishna A \& Tsutsui K $2011 b$ Effects of gonadotropin inhibitory hormone on folliculogenesis and steroidogenesis of cyclic mice. Fertility and Sterility 95 1397-1404. (doi:10.1016/j.fertnstert.2010.03.052)

Sinha Hikim AP \& Swerdloff RS 1999 Hormonal and genetic control of germ cell apoptosis in the testis. Reviews of Reproduction 4 38-47. (doi:10.1530/ror.0.0040038)

Smith A \& Haaf T 1998 DNA nics and increased sensitivity of DNA to fluorosence in situ end labeling during functional spermieogensis. BioTechniques 25 496-502.

Son YL, Ubuka T, Millar RP \& Tsutsui K 2012 Gonadotropin-inhibitory hormone inhibits GnRH-induced gonadotropin subunit gene transcriptions by inhibiting AC/cAMP/PKA-dependent ERK pathway in L $\beta$ T2 cells. Endocrinology 153 2332-2343. (doi:10.1210/en.2011-1904)

Tsutsui K 2009 Review: A new key neurohormone controlling reproduction, gonadotropin-inhibitory hormone $(\mathrm{GnIH})$ : Biosynthesis, mode of action and functional significance. Progress in Neurobiology 88 76-88. (doi:10.1016/j.pneurobio.2009.02.003)

Tsutsui K, Saigoh E, Ukena K, Teranishi H, Fujisawa Y, Kikuchi M, Ishii S \& Sharp PJ 2000 A novel avian hypothalamic peptide inhibiting gonadotropin release. Biochemical and Biophysical Research Communications 275 661-667. (doi:10.1006/bbrc.2000.3350)

Tsutsui K, Bentley GE, Bedecarrats GT, Osugi T, Ubuka T \& Kriegsfeld LJ $2010 a$ Review: Gonadotropin-inhibitory hormone (GnIH) and its control of central and peripheral reproductive function. Frontiers in Neuroendocrinology 31 284-295. (doi:10.1016/j.yfrne.2010.03.001)

Tsutsui K, Bentley GE, Kriegsfeld LJ, Osugi T, Seong JY \& Vaudry H 2010 b Review: Discovery and evolutionary history of gonadotrophininhibitory hormone and kisspeptin: new key neuropeptides controlling reproduction. Journal of Neuroendocrinology 22 716-727. (doi:10.1111/j. 1365-2826.2010.02018.x)

Tsutsui K, Ubuka T, Bentley GE \& Kriegsfeld LJ 2013 Review: regulatory mechanisms of gonadotropin-inhibitory hormone $(\mathrm{GnIH})$ synthesis and release in photoperiodic animals. Frontiers in Neuroscience 7 1-11. (doi:10.3389/fnins.2013.00060)

Ubuka T, Ukena K, Sharp PJ, Bentley GE \& Tsutsui K 2006 Gonadotropininhibitory hormone inhibits gonadal development and maintenance by decreasing gonadotropin synthesis and release in male quail. Endocrinology 147 1187-1194. (doi:10.1210/en.2005-1178)

Ubuka T, Kim S, Huang Y, Reid J, Jiang J, Osugi T, Chowdhury VS, Tsutsui K \& Bentley GE 2008 Gonadotropin-inhibitory hormone neurons interact directly with gonadotropin-releasing hormone-I and -II neurons in European starling brain. Endocrinology 149 268-278. (doi:10.1210/en.2007-0983)

Ubuka TLH, Kitani M, Suzuuchi A, Pham V \& Cadigan PA 2009a Gonadotropin-inhibitory hormone identification, cDNA cloning, and distribution in rhesus macaque brain. Journal of Comparative Neurology 517 841-855. (doi:10.1002/cne.22191)

Ubuka T, Morgan K, Pawson AJ, Osugi T, Chowdhury VS, Minakata H, Tsutsui K, Millar RP \& Bentley GE $2009 b$ Identification of human gonadotropin-inhibitory hormone homologs, RFRP-1 and RFRP-3, and the cognate receptor, GPR147 in the human hypothalamic pituitary axis. PLOS ONE 4 e8400. (doi:10.1371/journal.pone.0008400)

Ubuka T, Inoue K, Ukena K, Kriegsfeld LJ \& Tsutsui K 2012 Identification, expression, and physiological functions of Siberian hamster gonadotropin-inhibitory hormone. Endocrinology 153 373-385. (doi:10.1210/ en.2011-1110)

Ubuka T, Son YL, Tobari Y, Narihiro M, Bentley GE, Kriegsfeld LJ \& Tsutsui K 2014 Central and direct regulation of testicular activity by gonadotropin-inhibitory hormone and its receptor. Frontiers in Endocrinology 8 1-10. (doi:10.3389/fendo.2014.00008)

Ukena K, Iwakoshi E, Minakata H \& Tsutsui K 2002 A novel rat hypothalamic RFamide-related peptide identified by immunoaffinity chromatography and mass spectrometry. FEBS Letters 512 255-258. (doi:10.1016/S0014-5793(02)02275-5)

Ukena K, Ubuka T \& Tsutsui K 2003 Distribution of a novel avian gonadotropin-inhibitory hormone in the quail brain. Cell and Tissue Research 312 73-79.

Yin H, Ukena K, Ubuka T \& Tsutsui K 2005 A novel G protein-coupled receptor for gonadotropin-inhibitory hormone in the Japanese quail (Coturnix japonica): identification, expression and binding activity. Journal of Endocrinology 184 257-266. (doi:10.1677/joe.1.05926)

Yoshida H, Habata Y, Hosoya M, Kawamata Y, Kitada C \& Hinuma S 2003 Molecular properties of endogenous RFamide-related peptide-3 and its interaction with receptors. Biochimica et Biophysica Acta 1593 151-157. (doi:10.1016/S0167-4889(02)00389-0)

Zhao S, Zhu E \& Yang C 2010 RFamide-related peptide and messenger ribonucleic acid expression in mammalian testis: association with the spermatogenic cycle. Endocrinology 151 617-627. (doi:10.1210/ en.2009-0978)

Received in final form 28 July 2014

Accepted 19 August 2014

Accepted Preprint published online 19 August 2014 